MH EK Neurológia, Alvásdiagnosztikai és Terápiás Centrum

\title{
A csapatorvos és az alapellátás szerepe az alvás-ébrenléti zavarok diagnosztikájában
}

\section{Dr. habil Szakács Zoltán orvos ezredes, PhD}

Kulcsszavak: alvászavarok, kivizsgálási algoritmus, napközbeni aluszékonyság, alvásfregmentáció, hyperszomnia

Az alvás-ébrenlét zavarok sikeres kezelésének kulcsa a helyes és időben történő kórisme. Ennek megvalósítása azonban annak függvénye, figyelembe vesszük-e e terület néhány sajátos vonását. Tudnunk kell, hogy a betegek jelentős része ilyen természetü problémáját spontán nem említi, az egyértelmủ panaszokat és tüneteket is más okkal magyarázza; eltérö okok esetén is az alvászavar sokáig azonos panaszokhoz (pl. mentális, affektív deficit tünetekhez, napközbeni aluszékonysághoz stb.) vezethet. Az alvás során fellépő kísérő tünetekről csak a hálótárs, a családtagok tudhatnak. A betegek jelentős részének a gyógyulása az alvásmedicina speciális vizsgáló módszereinek (alvásdiagnosztika) és az azokhoz kapcsolódó csapatorvosi, szakorvosi körnek az aktív részvételét igényli.

Az alvás-ébrenléti zavarok diagnosztikájának sajátos vonásai

A megalapozott kórisme felállítása után a lehető leghamarabb el kell kezdeni a hatékony és a kiváltó ok megfelelő terápiát, mert a beteg teljesítménye, munkaképessége csökken, életkilátásai romlanak, szociális kapcsolatai károsodnak, baleset-veszélynek van kitéve. A késedelem a kóros állapotot fixáló, negatív kondicionálási folyamatokat, súlyos pszichés és szociális konfliktusokat indíthat el $[1,2]$.
Az alvás-ébrenléti zavarok időbeli vonatkozásai: A rövidtávú és krónikus alvás-ébrenlét zavarok

Elsőként is azt kell tisztáznunk, milyen hosszú ideje állnak fenn az alvás-ébrenlét zavarra utaló jellemző tünetek és panaszok (I. táblázat).

A rövidtávú alvásképtelenség esetén az alváselégtelenség tünetcsoportja átmenetileg, néhány napig, de két hétnél mindenképpen rövidebb tartamban jelentkezik. Gyakori, hogy a panaszok 


\section{I. táblázat. Az alvásfolyamat zavarára utaló tünetek}

\section{a. Az alvásfolyamat makrozavarai}

Elalvási inszomnia: az esti lámpaoltástól az elalvásig fél óránál hosszabb idő - nem egy esetben órák - telnek el.

Az átalvási inszomnia: az alvásfolyamatot 3-nál több alkalommal (minimálisan egy perc tartamú), vagy egy 30 percet meghaladó ébrenlét szakítja meg. A korareggeli inszomnia - átlagos életvitel mellett - a hajnali 3-4 óra körüli végleges felébredés.

b. Az alvásfragmentálódás.

Az alvás fiziológiás folyamatát számtalan, többnyire nem tudatosult, részleges, 15 másodpercnél rövidebb - többnyire rendellenes légzés/mozgásepizódhoz csatlakozó - ébredés tördeli szét.

2. Az ébrenlét zavarára utaló tünetek (szellemi-fizikai teljesitmény deficit, aluszékonyság).

Időben gyakran megelözik fenti tüneteket. Megfelelő szakmai protokoll segítségével igazolni lehet a kórképspecifikus (alvásfragmentáció-hypersomnia szindrómák, elsődleges hypersomniák, cirkadián alvás-ébrenlét zavarok) jellemzőket .

3. Az alvás-ébrenlét zavart kísérö jelenségek.

$\mathrm{Az}$ alvás-ébrenlét zavarait változatos jelenségek (pl. sajátos hangfenomén, mozgásjelenség, affektív tónusvesztés, pszichopatológiai szindrómák) kísérhetik. Kórjelző értékük eldöntése különösen a krónikus alvás-ébrenlét zavarok esetében jelentős.

visszatérő jelleggel észlelhetők, ez az alváselégtelenség intermittáló formája. Az esetek túlnyomó többségében szituációs stressz állapotot (alkalmazkodási zavar), nemritkán a jet lag, vagy a többmüszakos munkakörök átmeneti megterheléseit találjuk a háttérben. A rövidtávú alváselégtelenség mögött leggyakrabban akut testi betegség, pszichológiai természetű zavar (gyászreakció, évszakhoz kötődő allergiás folyamat), vagy elhúzódó szituációs stressz állapot áll.

A mind diagnosztikájában mind a kezelésében nagy körültekintést igénylő, gyakori krónikus alvászavarról beszélünk akkor, ha az alváselégtelenség egy hónapnál hosszabb ideig (nem ritkán hónapokig, évekig) áll fenn. A krónikus alvás-ébrenlétzavarok kivizsgálása az alapellátásból kiinduló, a szakorvosi rendelőkön, kórházi osztályokon keresztül, az alvásambulanciák közreműködésével az alváslaboratóriumokig tartó utat jelent, ami az egyedüli lehetőségét adja a valós ok (különösen elsődleges alváselégtelenség) feltárásának, a differenciál diagnosztikai szempontból elkülönítendő egyéb kórképek felismerésének, az eredményes kórképspecifikus (eszközös, pszichioterápiás és az altatók mellett gyakran más gyógyszerformákat is igénylő gyógyszeres) terápia megválasztásának (II. táblázat). 
II. táblázat. Az alvás-ébrenlét zavarok időtartamának, lehetséges okainak és a diagnosztikus/terápiás teendök kapcsolata

\begin{tabular}{|l|l|l|l|}
\hline Időtartam & \multicolumn{1}{|c|}{ Ok } & \multicolumn{1}{c|}{ Teendő } & \multicolumn{1}{c|}{ Terápia } \\
\hline $\begin{array}{l}\text { Átmeneti } \\
\text { (néhány } \\
\text { nap) }\end{array}$ & $\begin{array}{l}\text { Akut stressz, időzóna } \\
\text { váltás, testi betegség, } \\
\text { környezeti tényezők }\end{array}$ & $\begin{array}{l}\text { Okok } \\
\text { feltárása }\end{array}$ & $\begin{array}{l}\text { Alváshygiéné, kiváltó } \\
\text { tényezők tudatosítása, esetleg } \\
\text { hipnotikum }\end{array}$ \\
\hline $\begin{array}{l}\text { Rövidtávú } \\
(1-3 \text { hét) }\end{array}$ & $\begin{array}{l}\text { Szituációs stressz, pszichés } \\
\text { okok }\end{array}$ & $\begin{array}{l}\text { Okok } \\
\text { feltárása }\end{array}$ & fentiek + célzott pszichoterápia \\
\hline $\begin{array}{l}\text { Krónikus } \\
\text { (>1 hónap) }\end{array}$ & $\begin{array}{l}\text { Elsődleges alvás/ébrenlét } \\
\text { zavarok (alvási apnoe, } \\
\text { UARS, RLS/PLMD, } \\
\text { narcolepsia, cirkadián } \\
\text { ritmus zavarai), krónikus } \\
\text { pszichés/szomatikus } \\
\text { betegség, gyógyszerhatás, } \\
\text { környezeti ártalmak }\end{array}$ & $\begin{array}{l}\text { Okok } \\
\text { feltárása } \\
\text { a szakmai } \\
\text { protokollok } \\
\text { szerint }\end{array}$ & $\begin{array}{l}\text { Oki terápia: } \\
\text { a patomechanizmusnak } \\
\text { megfelelö eszköz (ld. CPAP) } \\
\text { pszichoterápia, } \\
\text { hipnotikum, speciális } \\
\text { gyógyszerek, alváshigiéne, } \\
\text { kronoterápia, illetve ezek } \\
\text { együttese }\end{array}$ \\
\hline
\end{tabular}

* Ellátásuk a szakorvosok, ezen belül az alvásambulanciák és alváslaboratóriumok feladata.

\section{Az alvás ébrenlét zavarok ellátási algoritmusa}

Az alvás-ébrenlét zavarok ellátásának sarokpontja tehát annak megállapítása, átmeneti, vagy krónikus alváselégtelenségröl van-e szó. Az átmeneti és rövidtávú formákban az ott megadott szabályok betartása mellett a csapatorvos és a háziorvos is sokat tehet. A krónikus esetek többségében azonban a diagnosztikai lánc további szintjeit is igénybe kell vennünk. Fontos, hogy betartsuk a diagnosztikus döntési fa egyes lépéseit (1. ábra). Tisztáznunk kell, van-e kóros hangfenomén, szokatlan mozgás alvás közben, kialakult-e zavaró aluszékonyság napközben, jelen vannak-e a pszichofiziológiai inszomnia ismérvei, a beteg több müszakban dolgozik-e, vagy alapbetegsége, illetve szedett gyógyszerei magyarázzák ilyen természetű panaszait [3].

\section{Szokatlan hangfenomén alvás közben}

Az alvás közben jelentkező szokatlan hangfenomén esetében a horkolás (egyszerü horkolás, felsőlégúti rezisztencia szindróma, obstruktív alvási apnoe), a köhögés-fuldoklás, stridoros légzés (oesophagus reflux szindróma, obstruktív alvási apnoe gyermekkorban, alvásbeli fuldoklás szindróma, aktuális légúti infekciók), a fogcsikorgatás (bruxizmus), az alvás közbeni beszéd, felsikoltás (éjszakai félelmes felriadás), illetve az epilepsziás roham jellemző hangfenoménja különítendő el.

Közülük a horkolás jelentősége kiemelkedő: Egyszerű, illetve kóros jellegének felismerése a beteg későbbi sorsára nézve meghatározó jelentőségü, ezt patomechanizmusának rövid összefoglalása egyértelművé teszi. A horkolás alvás közben a belégzés során fellépő re- 


\begin{tabular}{|c|c|c|}
\hline \multicolumn{3}{|l|}{ • VAN-E ALVÁS KÖZBEN? } \\
\hline $\begin{array}{l}\text { - KÓROS HANGJELENSÉG (horkolás, } \\
\text { vokalizáció,beszéd, fuldoklás) (OSA, UARS, } \\
\text { GERD, epilepszia, paraszomniák) }\end{array}$ & IGEN $\rightarrow$ & ALVÁSDIAGNOSZTIKA \\
\hline $\begin{array}{l}\text { - KÓROS MOZGÁSZAVAR (kényszermoz- } \\
\text { gás paraesthesiára, (PLMD, RLS, epilepszia, } \\
\text { paraszomniák, OSA) lábrángás, konvulziók, } \\
\text { durva, tömeges fuldokló mozgások, járkálás, } \\
\text { agresszív megnyilvánulások) }\end{array}$ & IGEN $\rightarrow$ & ALVÁSDIAGNOSZTIKA \\
\hline $\begin{array}{l}\text { - INTEZÍV/SZOKATLAN ÁLOMTEVÉ- } \\
\text { KENYSÉG (hipnagog hallucinációk, lidérces } \\
\text { álmok elalvás itáni nyomasztó álmok) }\end{array}$ & IGEN $\rightarrow$ & $\begin{array}{l}\text { ALVÁSDIAGNOSZTIKA } \\
\text { (narcolepsia, depresszió, } \\
\text { REM paraszomniák) }\end{array}$ \\
\hline $\begin{array}{l}\text { - VAN-E ALUSZÉKONYSÁG (EDS) NAP- } \\
\text { KÖZBEN? (permanens álmosság, alvásroha- } \\
\text { mok, viselkedési automatizmusok, átmeneti } \\
\text { látászavar, munka-és tanulási nehézségek, } \\
\text { gyakori közlekedési balesetek okozása) }\end{array}$ & IGEN $\rightarrow$ & $\begin{array}{l}\text { ALVÁSDIAGNOSZTIKA } \\
\text { (alvásfüggő légzés-és moz- } \\
\text { gászavarok, primer és tüneti } \\
\text { hypersomniák,depresszió). }\end{array}$ \\
\hline $\begin{array}{l}\text { - FELLELHETŐK-E A BETEGNÉL A } \\
\text { PSZICHOFIZIOLÓGIAI INSZOMNIA } \\
\text { TÜNETEI? }\end{array}$ & IGEN $\rightarrow$ & $\begin{array}{l}\text { ALVÁSAMBULANCIA, } \\
\text { ALVÁSDIAGNOSZTIKA }\end{array}$ \\
\hline $\begin{array}{l}\text { - ALKALMAZ-E A BETEG ALVÁS-ÉBREN- } \\
\text { LÉT ZAVART OKOZÓ GYÓGYSZERE- } \\
\text { KET? } \\
\text { Kimutathatók-e egyéb exogen tényezők? }\end{array}$ & $\mathrm{IGEN} \rightarrow$ & $\begin{array}{l}\text { ALVÁSSPECIALISTA } \\
\text { ÉS SZAKORVOS } \\
\text { EGYÜTTMÜKÖDÉSE }\end{array}$ \\
\hline $\begin{array}{l}\text { - SZENVED-E A BETEG ALVÁS-ÉBREN- } \\
\text { LÉT ZAVAR OKAKÉNT AZONOSÍTHA- } \\
\text { TÓ PSZICHIÁTRIAI,NEUROLÓGIAI } \\
\text { BELSZERVI BETEGSÉGBEN? }\end{array}$ & IGEN $\rightarrow$ & $\begin{array}{l}\text { SZAKORVOS / } \\
\text { ALVÁSSPECIALISTA } \\
\text { EGYÜTTMÜKÖDÉSE }\end{array}$ \\
\hline $\begin{array}{l}\text { - AZ ALVÁS-ÉBRENLÉT ZAVARBAN } \\
\text { SZENVEDÖ TÖBBMÜSZAKBAN } \\
\text { DOLGOZIK-E? }\end{array}$ & IGEN $\rightarrow$ & $\begin{array}{l}\text { ALVÁSSPECIALISTA } \\
\text { FOGLALKOZÁS- } \\
\text { EGÉSZSÉGÜGYI ORVOS } \\
\text { EGYÜTTMÜKÖDÉSE }\end{array}$ \\
\hline
\end{tabular}

OSA= obstruktív alvási apnoe, UARS= felsőléguti rezisztencia szindróma, $\mathrm{GERD}=$ oesophagus reflux szindróma, $\mathrm{PLMs}=$ periodikus lábmozgás szindróma, $\mathrm{RLS}=$ nyugtalan lábak szindróma

1. ábra. A teendőket meghatározó kérdések krónikus alváselégtelenség esetén

petitív hangfenomén, melyet az ellazult lágy szájpad és garatfal rezgése hoz létre. Ennek magyarázata az, hogy elalváskor a NREM alvás 2-e stádiumától kezdve a belégző izomzat tónusának változatlansága mellett hirtelen és jelentős mértékben csökken a garatfal izomzatának tó- nusa. Fiziológiás körülmények között (egyszerü horkolás esetében) müködik a garatot belégzés alatt nyitva tartó, a beáramló levegő garatfalra gyakorolt szívó hatását ellensúlyozni képes protektív reflex, így a garat keresztmetszete érdemi módon még nem válik szükebbé. 
A kóros horkolás megjelenésekor ez a reflexmechanizmus mind jobban károsodik, mind kiterjedtebb garatfal területek vonódnak be, melyek eltérő strukturális adottságaiknál fogva (lágy-szájpad, garatfal, uvula méretei, férfi-nő közti különbségek, kóros anatómiai strukturális változások) mind inkább az obstruktív alvásfüggő légzészavar (felső-légúti rezisztencia szindróma, obstruktív alvási apnoe) veszélyét jelző kóros horkolás hangfenoménjét produkálják. A protektív reflex késése e hangfenomén mellett a garat repetitív beszűküléséhez (hypopnoe), illetve időleges (>10 másodperc tartamú) elzáródásához (apnoe) vezet. A garat megnyitása ilyenkor már csak az al- vásfolyamatot fragmentáló, idővel kóros következményekkel (napközbeni aluszékonyság, arrhythmiák, kardioés cerebrovaszkuláris kórképek, kis- és nagyvérköri hypertonia, demencia) járó, szimpatikotóniás asphyxiás ébresztő reakciók árán jöhet létre. E reakciókat jelzik a garat megnyílását kísérő felhorkantások (III. táblázat)!

A horkolás egyszerü, vagy kóros jellege végső soron és biztonsággal az alvásdiagnosztikai vizsgálatok segitségével lehetséges, ami lényegében a gyanút felvetö és megerösitö alap- és elöszürésre épül és a végleges diagnózishoz nélkülözhetetlen, differenciál-diagnosztikai kérdéseket is eldönteni képes speciális alváslaboratóriumi vizsgálatokkal fejezödik be.

III. táblázat. A kóros és az egyszerü horkolást elkülönitö klinikai jellemzök

\begin{tabular}{|l|l|l|}
\hline & $\begin{array}{l}\text { Kóros (repetitív garatel- } \\
\text { záródásra utaló) horkolás }\end{array}$ & Egyszerü horkolás \\
\hline Gyakoriság & Minden alváskor & Idöszakosan \\
\hline Testhelyzet & $\begin{array}{l}\text { Mind több alváspozíció- } \\
\text { ban, nem egyszer ülve is }\end{array}$ & Inkább hanyattfekvő helyzetben \\
\hline Hangerő & $80-110 \mathrm{~dB}$ & $40-90 \mathrm{~dB}$ \\
\hline Hangfenomén & $\begin{array}{l}\text { Légzésritmust nem követi, } \\
\text { sípoló, hörgö, magas } \\
(100-1500 \mathrm{~Hz})\end{array}$ & $\begin{array}{l}\text { Légzésritmust követi, mélyebb } \\
(25-500 \mathrm{~Hz})\end{array}$ \\
\hline Légzés & $\begin{array}{l}\text { Egyenetlen, kihagyásokkal } \\
\text { Horkolás-apnoe-horkantás } \\
\text { triász }\end{array}$ & Egyenletes \\
\hline Alvásjellemzők & $\begin{array}{l}\text { Nyugtalan alvás, reggel } \\
\text { tompultság, aluszékonyság } \\
\text { napközben }\end{array}$ & Nyugodt alvás, kipihent ébredés \\
\hline Esti-reggeli RR hányadosa & $<1^{*}$ & $\geq 1$ \\
\hline $\begin{array}{l}\text { Az éjszakai RR ciklusos, } \\
\text { NREM-nek megfelelő } \\
\text { csökkenése }\end{array}$ & \begin{tabular}{l} 
Elmarad \\
\hline
\end{tabular} & Megtartott \\
\hline
\end{tabular}

* A kórosan horkoló betegek > 60\%-a hypertoniás. Minden (különösen non dipper) hypertoniás beteg esetében gondolni kell obstruktív alvási apnoéra! 


\section{Szokatlan mozgás- megnyilvánulások alvás közben}

Az alvást számos fiziológiás mozgásforma kíséri (elalvási rángások, fordulás, epizodikus kar-és lábflexiók, nyújtások, egy-egy mimikai megnyilvánulás, mormogás, nyelés. Ezek azonosítása, a mozgás ép, illetve kóros jellegének kimondás nagy tapasztalatot igényel.

Ismert, hogy az extrapyramidális kórképek is jellemző módon változnak alvás alatt sokszor igen súlyos alváselégtelenséget okozva.

$\mathrm{Az}$ alvás közbeni mozgások kóros megnyilvánulásai közé az alvásfüggő mozgászavarokat (nyugtalan láb szindróma, periodikus lábmozgások szindróma), több paraszomniát (bruxizmus, elalvási rángások, éjszakai paroxizmális dystonia, alvajárás, félelmes felriadás, alvásparalízis), az alváshoz kötődő epilepsziás rohamformákat, illetve az obstruktív alvási apnoe és az oesophagus reflux jellegzetes mozgásepizódjait soroljuk.

A diagnosztikus protokollban itt is megkülönbözethetjük az alap- az elöszürést és a speciális diagnosztikai szintet. A sajátosságot az alapszürésben a célzott kérdések (struktúrált kérdöivek), az elöszürés szintjén a neurográfia, a kiváltott válasz vizsgálatok, az aktigráfia, valamint a provokáló (immobilizációs) tesztek, a célzott laboratóriumi vizsgálatok; a speciális alváslaboratóriumi szinten a poliszomnográfia EMG és EEG csatorna számának tervszerü kiterjesztése jelentik

\section{Intenzív álomtevékenység alvás közben}

A REM fázisokban illetve azok környezetében felébresztett alvó az esetek többségében álomélményekről számol be. Általában a reggeli álomemlékek az utolsó, ébredés-közeli REM fázisból származnak. Ismert, hogy a REM fázisok gyakorisága és tartama az alvás második felében növekszik meg. Bizonyos kóros állapotokban azonban ez a szerkezet jellemző módon megváltozhat.

Az intenzív álomtevékenység időzítése, tartalma és kísérő jelenségei egyes kórképekre jellemzőek lehetnek

\section{Napközbeni aluszékonyság (Excessive Daytime Sleepiness EDS)}

1. Az Excessive Daytime Sleepiness az alvásdiagnosztikai laboratóriumok beteganyagának 60-70\%-ában jelentkező tünet-együttes, amely mentális deficittünetekből (globális memóriazavar, figyelemzavar); affektív deficittünetekből (irritabilitás, depresszió) és többnyire az alvás látszólagos folyamatossága ellenére fellépő, akaratlagosan nehezen, vagy alig kivédhető nappali alváskésztetésből áll (alvásrohamok, gyakoribb szunyókálás, memória és koncentráló képesség zavarai, automatikus cselekvésekkel kísért amnesztikus epizódok, kettős- és homályos látás stb.).

EDS-re gondolni kell azokban az esetekben is, amikor valaki sok és nehezen magyarázható balesetet követ el, romlik a szellemi teljesítménye, romlanak a szociális kapcsolatai, illetve nehezen magyarázható affektív változás, személyiségváltozás jeleit mutatja.

A betegek évek óta szenvednek általában a problémában anélkül, hogy az EDS, illetve a mögötte álló okok lehetösége felmerülne.

$A z$ EDS tünetcsoportja szubjektív módszerekkel (kérdőivek, pontozóskálák) és objektív alváslaboratóriumi protokollok (multiplex alvás-latencia teszt, ébrenmaradási készség teszt) segitségével vizsgálható. 
Az EDS mögött 4 eltérö

betegségcsoportra kell gondolnunk:

\section{a) Elsődleges hypersomniák}

E kórképeknél az alvásszabályozás rendszerében mutatható ki elsődleges és jellemző zavar, s ez jól tetten érhető mind az éjszakai alvás, mind a napközbeni aluszékonyság szerkezeti viszonyait kimutatni képes objektív poliszomnográfiás, poligráfiás elemzés segítségével.

A narcolepsia és az idiopathiás hypersomnia esetében a klinikai tünetek állandó, a jóval ritkább Klein-Levin szindróma esetében viszont (aluszékonyság, hyperphagia, inkább verbálisan megnyilvánuló szexuális szabatosság) a tünetek intermittáló megjelenésével kell számolni.

A narcolepsia esetében nem ritka, hogy a jól artikulált diagnosztikai kritériumok ellenére az első tünet megjelenésétől 10-15 év is eltelik a helyes diagnózis felállításáig A Gelinau által 1880-ban leírt klinikai tetrád (aluszékonyságalvásattackok, cataplexia, alvásparalízis, hypnagog hallucinációk) elemei ugyanis eltérő gyakorisággal, különböző életkorban jelennek meg a beteg életében, bár a klinikai tünetek leggyakrabban 15 és 30 éves kor között kezdődnek. A betegek 65\%-ában az EDS önálló tünet, 37\%-ában az EDS cataplexiával kombinálódik. Az alvásparalízis és a hypnagog hallucináció csupán 4\%-ban jelenik meg önállóan. Az EDS élethossziglan kíséri el a beteget, a többi tünetre sokszor jellemző, hogy csak egy-egy életszakaszban lépnek fel.

A megfelelö diagnosztika hiányában a leggyakoribb téves kórismék: epilepszia (myoclo-nusos-astaticus roham), TIA, drop attack, myasthenia, pszichiátriai kórkép. Utóbbiak különösen az atípusosan, önálló hypnagog hallucinációval és/ vagy alvásparalízissel járó esetekben merülnek fel. b) Alvásfragmentáció- hypersomnia szindrómák

Ezekben a kórképekben az alvás során fellépő, repetitív, nagyszámú, többnyire kórkép specifikus patogén epizód (hypopnoe, apnoe, felsőlégúti rezisztencianövekedés alvási apnoéban, jellemző mozgásepizódok periodikus lábmozgás szindrómában; ritkábban REM függő hypoventilatio elsődleges alveoláris hypoventilatio szindrómában, periodikus légzés Cheyne-Stokes légzésben), mikro-ébredések révén fragmentálja az alvás fiziológiás folyamatát. Mindez súlyos mély NREM illetve REM alvás deficitet (EDS-t, egyben az alvásébrenlét szabályozás, a légzés-keringés szabályozás,vegetatív idegrendszeri és anyagcsere szabályozás progresszív zavarát) okoz. Az alvásfüggő légzészavarok (elsősorban e csoport 90\%-át kitevő obstruktív alvási apnoe) emellett a súlyos nocturnalis $\mathrm{O}_{2}$ hiány következtében ezen felül organikus pszicho-szindrómákhoz vezetnek, többszörösére növelik cerebrovaszkuláris, kardiovaszkuláris katasztrófák, valamint a hypertonia rizikóját, csökkentik a várható élettartamot.

$\mathrm{Az}$ alvásdiagnosztika egyik legfontosabb feladata, hogy az EDS mögötttöbbnyire megfelelö elözetes gyanú esetén- idejében igazolja az alvás közbeni, kórkép-specifikus patogén epizódokat, valamint az alvásfragmentálódás és a napközbeni tünetek kapcsolatát.

A diagnosztika folyamata a háziorvosi, szakorvosi rendelökben kezdödik (alapszürés, elöszürés), majd az alváslaboratóriumban folytatódik

\section{c) Cirkadián alvás-ébrenléti zavarok}

A cirkadián alvás-ébrenlét zavarok túlnyomó részét az extrinsic formák adják, ahol a különböző módon megváltozott környezeti alvás-aktivitás viszonyok 
kényszerítik alkalmazkodásra a biológiai óra által vezérelt belső alvás-ébrenlét ritmust. Ez az időszak az időzónaváltás szindróma (jet lag) esetében átmeneti, a többmüszakos munkakörökben azonban évekig, évtizedekig tart. Az itt dolgozók kb. 70\%-ában krónikus alváselégtelenség és EDS alakul ki. E csoportnak igen nagy a gyakorlati jelentősége, hiszen a többmüszakos munkakörök kiemelt, balesetveszély szempontjából is érzékeny területeken (ipar, szállítás, egészségügy, honvédelem stb.) találhatók elsősorban.

A biológiai óra elsődleges zavarán alapuló formák ritkábbak. A késleltetett alvásfázis szindróma jellemzője a rendszerint éjfél utáni elalvás, délig tartó alvásfázis, szabályos alvásszerkezet, valamint az, hogy e jellemző napszaki alváspozíció külső szabályozó tényezőktől mentes helyzetekben (például szabadság idején is) fennmarad. A betegek képtelenek alkalmazkodni az átlagos napi munkarendhez. Az igen ritka korai alvásfázis szindróma esetében a következetes, kora hajnali ébredés jellemző. A nem 24 órás és a szabálytalan alvás-ébrenlét ritmus előfordulása sporadikus.

\section{d) Tüneti hypersomniák}

1. A vizsgálatoknak természetesen azokra a neurológiai, pszichiátriai és belgyógyászati kórképcsoportokra (koponyatrauma, agydaganat, a központi idegrendszer gyulladásai, cerebrovszkuláris inzultusok, krónikus fáradékonyság szindróma, fibromialgia, alkohol-drogabúzus, atípusos szezonális depresszió, hypothyreosis, Addison és Cushing kór, krónikus obsruktív tüdőbetegségek, szívelégtelenség, metabolikus zavarok/és lehetséges gyógyszer-

IV. táblázat. A szürési-gondozási rendszer felépitése

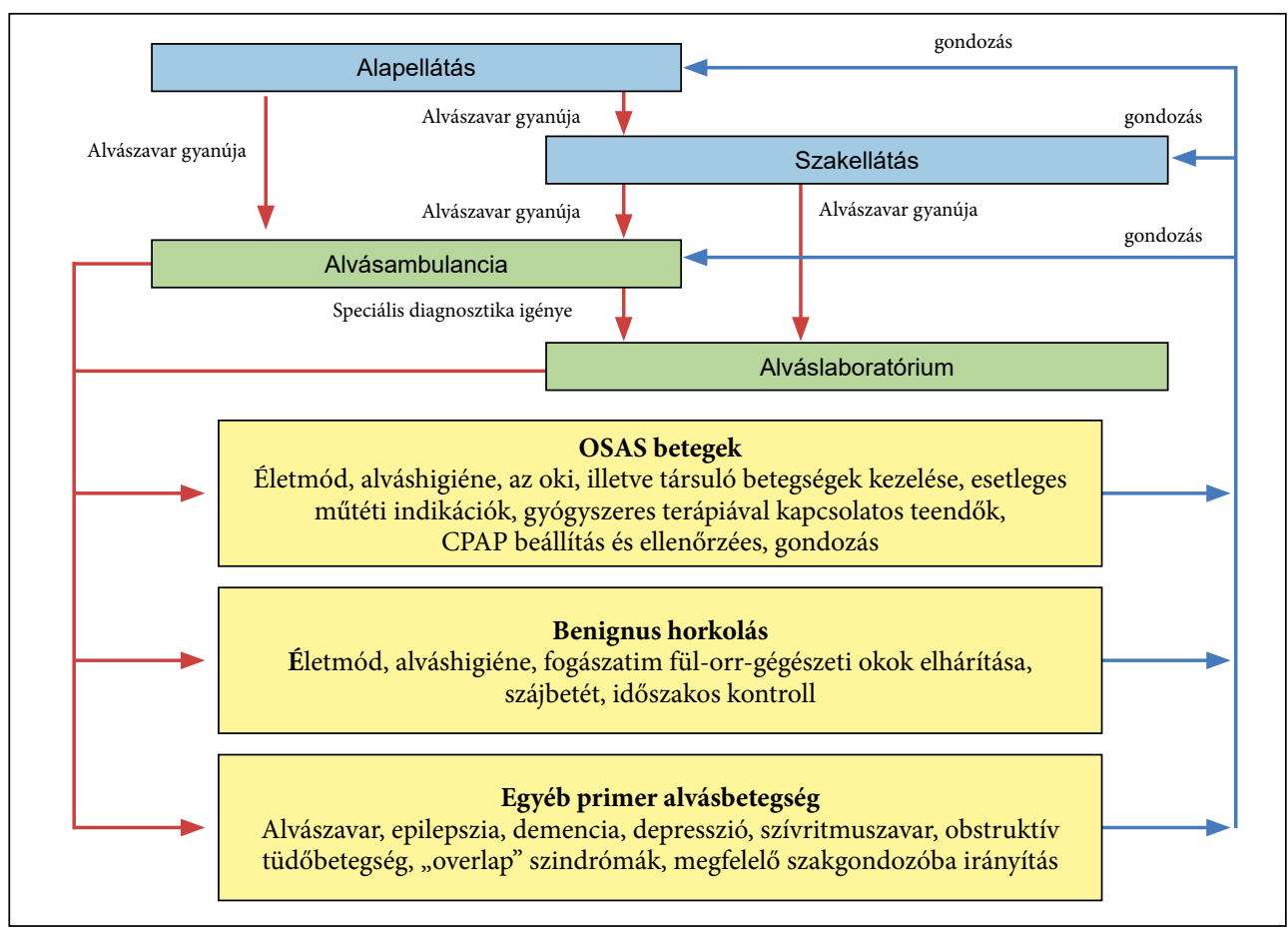


V. táblázat. Az alvásfolyamat másodlagos zavarát okozó kórképek

\section{Neurológia}

Cerebrovaszkuláris kórképek

Neuromuszluáris kórképek

Gyulladások, traumák

Fatális familiaris inszomnia
Belgyógyászat

Hyper- / hypothyreosis

Krónikus tüdő- és vesebetegségek

ISZB, szívritmuszavarok

Oesophagus reflux

Májbetegségek

\section{Pszichiátria}

Affektiv, szorongásos,

pszichoszomatikus kórképek

Schizophrenia

Személyiségzavarok

hatásokra is ki kell terjednie, amelyek a tüneti hypersomnia esetében számba jöhetnek. E csoport rendkívül heterogén, de gondos elemzésük minden egyes beteg esetében elkerülhetetlen, hiszen az EDS mögött első megközelítésben mindig több ok együttes lehetőségét kell felételeznünk (pl. súlyos OSAS beteg rejtett koponyasérülése kapcsán kialakult subdurális haematómája.

2. Fontos annak a tisztázása is, hogy jelen vannak-e a krónikus alvás-ébrenlét zavarok jelentős részét kitevő pszichofiziológiai inszomnia pszichopatológiai jegyei (Alvásra ösztönző környezetben ébresztő reakció kondicionálódik, szomatizált szorongás, napközbeni fáradtság és álmosság, akaratlan elalvás napközben, teljesítményt gátló szorongás, az alváspróbálkozás frusztrációhoz vezet, szokatlan környezet jobban segíti az alvást, az ágyban ébren töltött idő túlértékelődik).

3. Tisztázni kell az alvás-ébrenlét zavart esetleg okozó külső tényezőket leggyakrabban a különböző szakmai területeken alkalmazott gyógyszereket, illetve az egyéb, kisebb gyakorlati jelentőségü exogen tényezőket.
4. Fel kell ismerni természetesen az alvás-ébrenlét zavar esetleges oki öszszefüggéseit azokkal a belgyógyászati, neurológiai és pszichiátriai betegségekkel, melyek vagy önmagukban, vagy a szükségessé váló gyógykezelés következményeképpen járnak az alvásfolyamat károsodásával és egyaránt igénylik a szakorvosok, az alvásspecialista, esetenként a megfelelően megválasztott alvásdiagnosztika együttműködését

\section{Az alvás-ébrenlét zavarok ellátása és az egészségügy ellátó rendszere}

Az eddigi nemzetközi és hazai tapasztalatok arra utalnak, hogy az az ellátó rendszer müködik jól, melyben az ellátás folyamata a háziorvosi rendelökben, szakorvosi rendelőkben és kórházi osztályokon kezdődik, majd az alvásambulanciánkon keresztül az alváslaboratóriumokig terjed (IV. táblázat)

\section{A csapatorvos és a háziorvos szerepe}

$\mathrm{Az}$ alapellátásban elfoglalt központi helyzete révén a csapatorcvos és a háziorvos vetheti fel a leggyakrabban az alvás-ébrenlét zavar gyanúját. 
1. Mindenekelött a klinikai kép alapján, megfelelő ismeretek birtokában gondolnia kell az adott alvás-ébrenlét zavarra, a felmerült gyanút családi és egyéni kórtörténet ismeretében, a betegről birtokában lévő legnagyobb információ menynyiség kihasználásával megerösítheti.

2. Megalapozhatja a gyanút előzetes vizsgálatokkal

3. Elöszürést végezhet bizonyos irányokban. Időben alvásambulanciára, a szükséges szakorvosi vizsgálatokra alváslaboratóriumba irányíthatja a beteget

4. A háziorvos ugyanakkor nélkülözhetetlen partnere az alvásmedicinának a krónikus alvás-ébrenlét zavarban szenvedők gondozásában.

\section{Szakrendelők, kórházi osztályok}

Az alvás-éberség zavarok különböző formái nagy számban fordulnak meg a szakrendelők és kórházi osztályok beteganyagában is. Különösen az alvásfüggö légzészavarok (obstruktív alvási apone), illetve a hypersomniák esetében jellemző, hogy a betegeket az egyes diszciplinák a következményes tünetekkel (hypertonia, szívritmuszavar, demencia stb.) kezelik. A szakrendelőknek és kórházi osztályoknak fontos szerep jut az alvás-éberség zavarok ellátásában. Alvásfüggő légzészavarok esetében a neurológia, pulmonológia, gyermekgyógyászat, fül-orr-gégészet, kardiológia, gasztroenteorológia, fogászat; alvásfüggő mozgászavarok esetében a neurológia, elektrofiziológia; hiperszomniák esetében a neurológia, pszichiátria, belgyógyászat, pulmonológia; pszichiofiziológiai inszomnia esetében a pszichológia jelentőségét kell kiemelni $[4,5]$.

\section{Az alvásambulanciák}

$\mathrm{Az}$ alvásambulanciák szerepe kulcsfontosságú az alvásmedicina ellátó rendszerében. $\mathrm{Az}$ alvásmedicinában jártas szakorvos speciális szakértelménél fogva, mint konziliárius jelentős mértékben megkönnyítheti és meggyorsíthatja a diagnosztikus munkát, hiszen gazdaságosabb és hatékonyabb protokollt képes összeállítani, jobban meg tudja fogalmazni az igényeket az alváslaboratóriumok és szakorvosok számára. Hatékonyabban tudja ellenőrizni, vagy tanácsokkal segíteni a terápiát. Fontos, regionális irányító szerepe lehet a képzésben és a továbbképzésben. Az alvásambulanciához (alvásdiagnosztikában jártas szakemberhez) az alábbi esetekben ajánlatos fordulni:

1. Ha az alvás-ébrenlét zavart nem tudjuk megoldani

2. Ha a beteg az alkalmazott kezelésre belátható időn belül nem javul

3. Ha elsődleges alvászavar (alvási apnoe, alvásfüggő mozgászavar, pszichofiziológiai inszomnia, hypersominák valamelyik formája, alvásértékelési zavar, alváshygiénés problémák, cirkadián alvás-ébrenlét ritmus valamilyen zavara) alapos gyanúja merül fel.

\section{Az alváslaboratóriumok és centrumok feladatai}

Feladatuk a végső diagnózis felállítása megfelelően elökészített és tervezett alváslaboratóriumi vizsgálatok (protokollok) segítségével. A nemzetközi standardoknak megfelelö, poliszomnográfiával felszerelet alváslaboratóriumnak, kórházi, fekvőbeteg háttérrel kell rendelkezniük, biztosítaniuk kell a betegek megfelelő elhelyezését, a speciális 
szakorvosi vizsgálatokat, rendelkezniük kell intenzív terápiás részleg kapcsolatával, továbbá biztosítaniuk kell a specifikus terápiákhoz a szükséges körülményeket és eszközöket $[6,7,8]$ (V. táblázat).

\section{Irodalom}

[1] Szakács Z., Köves P.: Alvás-ébrenlét zavarok sajátosságai a katonai szolgálat körülményei között. Honvédorvos, 2005, 57(1-2): 30-41.

[2] Köves P., Szakács Z.: Az alvásmedicina katasztrófaorvostani és katonaorvosi vonatkozásai. Honvédorvos, 1994, 46(1): 32-48.

]3] Szakács $Z .:$ Az alvásfüggő légzés és mozgási zavarok, hiperszomniák diagnosztikus és terápiás algoritmusai. Háziorvos Továbbképző Szemle, 2000, 5(5): 299-303.

[4] Szakács Z., Ádám Ágnes, Annus J. K. et al.: A Magyar Alvásdiagnosztikai és Terápiás Társaság módszertani ajánlása a közúti jármủvezetők egészségi alkalmasságának vizsgálatához az obstruktív alvási apnoe szindróma vonatkozásában. Orvosi Hetilap, 2016, 157(23): 892-900.

[5] New Standards and Guidelines for Drivers with Obstructive Sleep Apnea syndrome - Report of the Obsrtuctive Sleep Apnoea Working Group. European Commission, Directorate- General for Energy and Transport, Brussels, 2013. http://researchrepository.ucd.ie/bitstream/handle /10197/6809/EU_sleep_apnoea.pdf sequence $=1$

[6] Köves P., Szakács Z., Bernáth I., Molnár M.: Cognitive deficits in obstuctive Sleep Apnea. SLEEP, 2001, 24: Abstract Suppl. 2001, A287.

[7] Szakács Z., Köves P., Molnár M., Farkasinszki Éva: Neuropsychological Assessment of Patients Treated For Obstructive Sleep Apnea Syndrome. Journal of Sleep Research, 2004, 13: Suppl. 1, October 2004, 695

[8] Szakács Z.: Paraszomniák és alvás alatti epilepsziák jelentősége és differenciáldiagnosztikája. Honvédorvos, 2005, 57(1-2): 30-41.

\section{Col. Z. Szakács MDMC, PhD}

\section{The role of the military physician and primary care in diagnosing sleep-wake disorders}

The key to the successful treatment of sleep-wake disorders is correct and timely diagnosis. However, the realization of this depends on taking into account some specific features of this field. We should be aware that the vast majority of patients do not spontaneously mention this kind of problem, but also explain the obvious complaints and symptoms for other reasons; for a variety of reasons, sleep deprivation can lead to the same symptoms for a long time (eg. mental, affective deficit symptoms, daytime sleepiness, etc.). Only the roommate, the family, is aware of the accompanying symptoms during sleep. The healing of a significant number of patients requires the active participation of special examination methods of sleep medicine (sleep diagnostics) and the related team of doctors and specialists.

After establishing a well-established disease, effective and effective therapy should be initiated as soon as possible, as the patient's performance, working capacity, life expectancy, social relationships and accident risk are reduced. Delay can trigger negative conditioning processes, severe psychological and social conflicts that fix the condition.

Key-words: sleep disorders, diagnostic algorithm, excessive daytime sleepiness, sleep fragmentation, hypersomnia

Dr. Szakács Zoltán o. ezds., PhD 1134 Budapest, Róbert Károly krt. 44. 